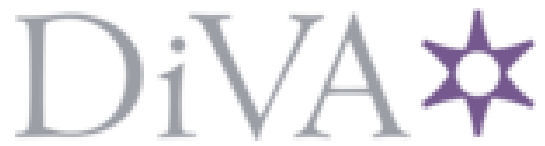

http://www.diva-portal.org

Preprint

This is the submitted version of a chapter published in The Palgrave handbook of family firm internationalization.

Citation for the original published chapter:

Kuiken, A., Naldi, L., Nordqvist, M. (2021)

Internationalization of family firms as a discontinuous process: The role of behavioral theory

In: T. Leppäaho \& S. Jack (ed.), The Palgrave handbook of family firm

internationalization (pp. 135-171). Cham: Palgrave Macmillan

https://doi.org/10.1007/978-3-030-66737-5

N.B. When citing this work, cite the original published chapter.

Permanent link to this version:

http://urn.kb.se/resolve?urn=urn:nbn:se:hj:diva-52967 


\title{
Internationalization of Family Firms as a Discontinuous Process: the Role of Behavioral Theory
}

Andrea Kuiken

University of Groningen

a.kuiken@,rug.nl

$+31503633458$

Lucia Naldi

Jönköping International Business School

Mattias Nordqvist

Stockholm School of Economics

\begin{abstract}
Prior research on internationalization of family firms relies on an, often implicit, assumption that internationalization is a continuous process, that is, they engage in an ongoing and increasing level of international activities. However, in reality internationalization is often a discontinuous process in which firms internationalize, de-internationalize, and potentially, reinternationalize. In the conceptual study presented in this chapter, we suggest that the behavioral theory of the firm and the four key concepts of quasi resolution of goal conflict, uncertainty avoidance, problemistic search, and learning, can provide a theoretical framework for understanding family firms' internationalization as a discontinuous process. While literature on family firms' internationalization builds on and borrows parts of the behavioral theory of the firm like considering the notions of multiple goals and uncertainty avoidance, other concepts of problemistic search and learning have received less attention. Following a review of literature on family firms' internationalization, we introduce new areas for empirical research and relevant research questions about family firms' internationalization as a discontinuous process based on key concepts of the behavioral theory of the firm.
\end{abstract}


Keywords: Family business, discontinuous internationalization, de-internationalization, reinternationalization, behavioral theory of the firm 


\section{Introduction}

Following the first article on internationalization of family firms by Gallo and Sveen (1991) research in this area has steadily increased (Casillas \& Moreno-Menéndez, 2017; Kontinen \& Ojala, 2010; Pukall \& Calabrò, 2014). Family firms are firms where the majority shareholding is owned by family members and the family controls the firm through involvement in management and/or the board of directors (e.g. Gallo \& Sveen, 1991; Sharma, 2004). Family firm owners have a large part of their wealth invested in the firm and because family members are often involved in managing the firm, family firms' internationalization decisions are influenced by financial and non-financial goals (Gómez-Mejía, Haynes, Núñez-Nickel, Jacobson, \& Moyano-Fuentes, 2007). Prior research has mainly studied whether family firms internationalize more or less than non-family firms (e.g. Fernández \& Nieto, 2005; George, Wiklund, \& Zahra, 2005; Sciascia, Mazzola, Astrachan, \& Pieper, 2012; Zahra, 2003) or which family firm characteristics influence its internationalization (e.g., Arregle, Naldi, Nordqvist, \& Hitt, 2012; Calabro, Brogi, \& Torchia, 2016; D’Angelo, Majocchi, \& Buck, 2016).

While internationalization-commonly defined as the involvement in activities across national boarders (Jones, 1999, 2001; Welch \& Luostarinen, 1988)-is a process in nature (Metsola et al., 2020), only a few existing studies (Graves \& Thomas, 2008; Kontinen \& Ojala, 2012) have adopted a processual and longitudinal perspective on family firms' internationalization and studied their internationalization paths. In addition, reviews of these process-based studies conclude that family firms tend to gradually internationalize as is predicted by the Uppsala model (Metsola et al., 2020, Pukall \& Calabró, 2014). Thus, these studies conceptualize internationalization as a continuous process in which it is assumed that once a family firm has entered a foreign market it stays there and over time it continues to increase its commitment in terms of investments, sales, and geographical presence in this market. 
However, internationalization is associated with a variety of challenges as a result of which a family firm's internationalization is often better characterized as a discontinuous process. Internationalization as a discontinuous process entails that firms do not necessarily continue to grow internationally over time, but that firms can go through periods of deinternationalization and potential re-internationalization. De-internationalization can take different forms like a complete stop to all international activities, a reduction in international scope by withdrawing from one foreign market but not from others, or a reduction in commitment to a market through a change in its operational mode (Benito \& Welch, 1997; Turcan, 2011). After a time-out period, firms may renew their international operations by reentering foreign markets that they previously de-internationalized from, enter new foreign markets, or use a higher-commitment operation mode, which is referred to as reinternationalization (Welch \& Welch, 2009; Vissak, 2010). Re-internationalization is different from the initial foreign market because the willingness to and process of re-internationalization are influenced by past international experience (Crick, 2004; Javalgi, Deligonul, Dixit, \& Cavusgil, 2011; Welch \& Welch, 2009).

Despite increasing interest among scholars in international business (Benito \& Welch, 1997; Bernini, Du, \& Love, 2016; Dominguez \& Mayrhofer, 2017; Surdu, Mellahi, \& Glaister, 2018a; Vissak, Francioni, \& Musso, 2012), internationalization as a discontinuous process is poorly understood in the context of family firms both conceptually and empirically. In this conceptual chapter, we argue that refocusing attention on the theoretical framework of the behavioral theory of the firm provides a theoretical background for conceptualizing internationalization of family firms as a discontinuous process and identifying important areas for empirical research to understand this phenomenon and its complexity.

The behavioral theory of the firm aims at understanding how micro-processes in a firm explain its decisions relating to aspects like price and output (Cyert \& March, 1963). The 
behavioral theory of the firm has been highly influential in business research in general (Gavetti, Greve, Levinthal, \& Ocasio, 2012), and in international business and family business research in particular. The Uppsala model (Johanson \& Vahlne, 1977), as the main internationalization process model, is directly related to the behavioral theory of the firm through the incorporation of problemistic search, uncertainty avoidance, and learning. Not only internationalization process literature has built on the behavioral theory of the firm, family business research is also directly and indirectly influenced by the behavioral theory of the firm. For example, in line with the behavioral theory of the firm, family business scholars have recognized that a variety of goals can exist within a family firm which can conflict with each other (Kotlar \& De Massis, 2013; Tagiuri \& Davis, 1992). Moreover, literature on family firm risk taking and the related concept of socioemotional wealth (SEW) - defined as non-financial aspects of the firm that meet the family's affective needs (Gómez-Mejía et al., 2007) - rely on the idea of the behavioral theory of the firm in that decisions are influenced by a potential failure to meet non-financial goals. Hence, literature on internationalization processes and family firms is rich, but it only borrows part of the concepts and ideas of the behavioral theory of the firm and disregards others.

In this chapter, we first analyze existing literature on family business internationalization and present how the behavioral theory of the firm has contributed to this field. To structure this analysis, we rely on Cyert and March's (1963) four key concepts to understand decisionmaking: 1) quasi resolution of conflict, 2) uncertainty avoidance, 3) problemistic search, and 4) learning. We then discuss how the existing use of the behavioral theory of the firm can contribute to an understanding of family firm internationalization as a discontinuous process and identify areas in the behavioral theory of the firm which have not been used but could potentially contribute to an understanding of internationalization as a discontinuous process. Although the behavioral theory of the firm can also provide avenues for future research on the 
internationalization process of family firms in general, we focus on de-internationalization and re-internationalization as key elements of internationalization as a discontinuous process. Specifically, we seek to provide a conceptual background for understanding the internationalization of family firms as a discontinuous process and identifying central concepts. We also suggest specific areas and questions for future research.

\section{Theoretical Background}

\section{Family firms and internationalization}

In their pioneering article Gallo and Sveen (1991) listed a number of factors that can stimulate and restrain the internationalization of family firms which have formed the basis of a growing body of research on family firms' internationalization. The dominant question in existing research is: how do family ownership influence the likelihood of a family firm's internationalization and the degree of internationalization? To answer this question, researchers have adopted two opposing approaches: the restrictive approach and the facilitating approach (Arregle, Duran, Hitt, \& Van Essen, 2017). Although Gallo and Sveen (1991) put forward that family firms have characteristics that can facilitate internationalization as well as characteristics that can restrain internationalization, these approaches emphasize one or the other. According to the restrictive approach, family firms internationalize less than non-family firms due to factors like limited resources (Arregle et al., 2012; Fernández \& Nieto, 2005; Graves \& Thomas, 2008; Liu, Lin, \& Cheng, 2011a), lack of necessary managerial capabilities (Graves \& Thomas, 2006), risk aversion (Claver, Rienda, \& Quer, 2007), strong reliance on local networks (Kontinen \& Ojala, 2011b) and a fear of losing SEW (Gomez-Mejia, Makri, \& Kintana, 2010). The facilitating approach emphasizes that, aspects like patient capital (Zahra, 2003), greater alignment of interests within the firm (Chen, Hsu, \& Chang, 2014), and altruism (Calabro et al., 2016) increase the likelihood of family firms' internationalization. In response 
to these mixed findings, family firms' internationalization literature examines several forms of heterogeneity.

Heterogeneity in research on family firms' internationalization most often refers to differences in ownership and control. For example, Sciascia et al. (2012) reconcile the mixed findings by examining an inverted U-shaped relationship between family ownership and internationalization and showing that the internationalization of family firms is maximized at moderate levels of family ownership. Others (Alessandri, Cerrato, \& Eddleston, 2018; Arregle et al., 2012; D'Angelo et al., 2016) examine the influence of external involvement - defined as involvement of non-family members - in a firm's management and its board of directors. External involvement can provide access to resources, knowledge, and capabilities which can reduce concerns about SEW, reduce bifurcation bias and, as a result, increase the degree and pace of internationalization (Arregle et al., 2012; Calabro, Campopiano, Basco, \& Pukall, 2017; Calabrò, Mussolino, \& Huse, 2009; D’Angelo et al., 2016). Similarly, having multiple owners can provide access to resources for internationalization and stimulate family firms' international growth (Fernandez \& Nieto, 2006). Whereas, having another family firm as owner might have little impact on internationalization, financial institutions might positively influence international diversification (Sanchez-Bueno \& Usero, 2014). Another source of heterogeneity within family firms can be the generational involvement in a firm. Gallo and Sveen (1991) put forward that a new generation entering the business can be a reason for family firms to internationalize. Incoming generations can have different perceptions and knowledge about internationalization and risk-taking, and as such a new generation taking over a firm can spur internationalization (Calabro et al., 2016). However, if family firms have not internationalized in the first and second generations, they are unlikely to internationalize after this (Okoroafo \& Koh, 2009). 
Heterogeneity can also relate to different internationalization strategies that family firms pursue. A rich stream of literature has emerged on the influence that family firm heterogeneity has on internationalization though only a few studies consider heterogeneity in the internationalization strategies that are pursued by family firms (Hennart, Majocchi, \& Forlani, 2017). Generally, it is argued that if family firms internationalize, they will internationalize into markets that are relatively close so as to reduce risks of losing SEW (Gomez-Mejia et al., 2010). However, a more nuanced understanding can be achieved by combining heterogeneity of family firms with different internationalization strategies. In line with this, Banalieva and Eddleston (2011) distinguish between a home-region strategy and a global strategy and find that family firms with family leaders tend to have a stronger home-region focus, whereas non-family leaders are beneficial for pursuing a global strategy. Moreover, family firms that sell niche market products are less affected by the factors that restrain the internationalization of family firms and hence they are more likely to adopt a global strategy (Hennart et al., 2017).

Export is the dominant mode of internationalization documented in studies on small,- and medium-sized family firms' internationalization (e.g., D’Angelo et al., 2016; Fernández \& Nieto, 2005; Sciascia et al., 2012). Interestingly, Arregle et al. (2017) did not find any difference between family and non-family firms measuring internationalization as exports. But differences were observed when the focus was on foreign direct investment (FDI). The adoption of international operation modes that require higher international commitment like FDI, is associated with a long term vision and the presence of non-family managers (Claver, Rienda, \& Quer, 2009). When adopting a foreign operation mode which requires higher commitment, family firms are more likely to follow a greenfield strategy rather than acquiring a foreign subsidiary because greenfield investments are more flexible, can be gradually build, can be better controlled, and tend to be less complex than international acquisitions (Boellis, Mariotti, Minichilli, \& Piscitello, 2016). 
The few existing studies that examine the internationalization process of family firms (Claver et al., 2007; Graves \& Thomas, 2008; Kontinen \& Ojala, 2012) follow the Uppsala model and are based on case research. In the Uppsala model, firms first enter markets that are relatively close and over time increase their international commitment (Johanson \& Vahlne, 1977). More generally, studies on the internationalization of family firms tend to focus more on describing the process, than explaining why it occurs in the first place. These studies tend also to rely on the implicit assumption that internationalization is a continuous process. As mentioned, recent literature on internationalization challenge this assumption and acknowledge that firms might follow a discontinuous process in which they can internationalize, deinternationalize, and re-internationalize (Bernini et al., 2016; Dominguez \& Mayrhofer, 2017; Vissak, 2010).

\section{Internationalization as a discontinuous process}

Internationalization is often described as a process of continuous growth-increasing involvement in international activities — though in reality it is more likely to be a discontinuous process which entails periods of internationalization, de-internationalization, and reinternationalization (Welch \& Paavilainen-Mäntymäki, 2014; Vissak, 2010). An abundant amount of research exists on internationalization which examines issues like internationalization decisions, processes, timing, entry modes, and market choices (Buckley \& Casson, 1998; Ellis, 2011; Johanson \& Vahlne, 1977; Oviatt \& McDougall, 1994). Even though there is a rich understanding of internationalization, episodes in which firms de-internationalize and re-internationalize and the connections between these different episodes are less understood. Relatedly, some scholars have even questioned the extent to which internationalization literature has truly conceptualized internationalization as process (Welch et al., 2016). 
From a discontinuous perspective, de-internationalization is defined as reduced involvement in foreign operations. As such it includes complete withdrawal from foreign markets, changes in operation modes, or a reduction in the breadth and depth of foreign operations (Benito \& Welch, 1997; Turcan, 2011). Financial reasons, like poor performance abroad and a firm's inability to sustain foreign operations, are put forward as major reasons for de-internationalization (Boddewyn, 1979; Sousa \& Tan, 2015). However, also other antecedents have been identified. Internal factors that potentially influence deinternationalization include changes in leadership (Cairns, Quinn, Alexander, \& Doherty, 2010), international experience (Choquette, 2018; Delios \& Beamish, 2001), strategic fit (Sousa \& Tan, 2015), and speed of internationalization (Mohr, Batsakis, \& Stone, 2018). Examples of external factors are changes in exchange rates and tariffs (Fitzgerald \& Haller, 2018) and a decline in demand in the host country (Benito, 1997). In addition, scholars (Boddewyn, 1983; Jackson, Mellahi, \& Sparks, 2005; Matthyssens \& Pauwels, 2000) have investigated the deinternationalization process rather than the motivation for de-internationalization. Boddewyn (1983) suggests a process that starts with detecting a discrepancy in the foreign environment which results in a performance that is below aspirations, followed by a period in which limited action is taken due to exit barriers. For de-internationalization to take place, a firm often needs a new manager who can persuade the management team and organize support for deinternationalization. Matthyssens and Pauwels (2000) describe the de-internationalization process as one where firms simultaneously go through a process of escalating commitment and creating strategic flexibility.

After a time-out period from a foreign market, firms can decide to re-internationalize by re-entering markets that they previously de-internationalized from, re-entering other foreign markets, or increasing their commitment to foreign markets by changing their operation modes (Welch \& Welch, 2009). The de-internationalization experience is likely to influence re- 
internationalization, a negative experience can result in lack of confidence in a foreign market, and a residual mindshare might make re-entry into an international market difficult (Javalgi et al., 2011). However, since managers tend to learn more from their failures than from their successes (Shepherd, 2003), de-internationalization can also result in learning and a redefinition of the internationalization strategy. Surprisingly, recent studies suggest that prior experience does not increase the speed of re-entry (Surdu, Mellahi, Glaister, \& Nardella, 2018b); it also does not result in changes in the degree of commitment when the firms re-enter (Surdu et al., 2018a).

Instead of studying one of the episodes, some studies have examined internationalization as a discontinuous process by considering de-internationalization and re-internationalization together. Early studies focus on establishing that the internationalization process can be discontinuous (Vissak \& Francioni, 2013; Vissak et al., 2012), whereas later studies have started to explain the reasons and mechanisms underlying such a discontinuous process. For example, intermittent exporting as an example of a discontinuous internationalization process is found to be strongly influenced by changes in the external environment (Bernini et al., 2016). Dominguez and Mayrhofer (2017) relate a variety of internal and external factors to different stages in a discontinuous internationalization process. They find that foreign divestment is mainly associated with lack of preparation, knowledge, and access to networks as well as loss of competitiveness in the market, whereas re-internationalization is triggered by changes in ownership in combination with growing foreign demand.

Thus, international business scholars have started recognizing that internationalization can be discontinuous but research on family firms' internationalization sees internationalization as a static presence, or a continuous process at best. As Reuber (2016) concluded, it would be valuable to complement existing approaches with one that considers the temporality and dynamics of the internationalization of family firms and the family as a major actor in this. In 
addition, Welch et al. (2016: 794) reclaim the importance of the behavioral paradigm, where process is embedded, and managerial decisions are 'history dependent'. Relatedly, Coviello, Kano, and Liesch (2017) make a plea for considering the role of individuals - that is, the decision makers either individually or as part of a group, including families - as a core microfoundation of the internationalization process, while Håkansson and Kappen (2017) proposes an alternative model of the internationalization process of the firm, where firms enter foreign markets in wave-like patterns rather than incrementally. What is needed for this is a theory which provides a process perspective including insights into the micro-processes underlying family firms' internationalization (Reuber, 2016). In the next section, we argue that the behavioral theory of the firm, which has influenced research on family firms as well as research on the internationalization process, can provide an appropriate theoretical lens for studying family firms' internationalization as a discontinuous process.

\section{Internationalization of Family Firms and the Behavioral Theory of the Firm}

\section{Theories used in research on family firms' internationalization}

A large number of studies on family firms' internationalization rely on agency theory or stewardship theory (e.g., Banalieva \& Eddleston, 2011; George et al., 2005; Graves \& Shan, 2014; Sciascia et al., 2012). Since the introduction of the SEW (Gómez-Mejía et al., 2007), many studies refer to the notion of SEW in their arguments (e.g., Alessandri et al., 2018; Boellis et al., 2016; Sanchez-Bueno \& Usero, 2014) but only a few measure SEW or one of its dimensions and its impact on family firms' internationalization (Cesinger et al., 2016b; Kraus, Mensching, Calabrò, Cheng, \& Filser, 2016). Alternatively, scholars adopt a resource-based view or a resource dependence perspective to argue that family firms have a different set of resources which influence their internationalization (Arregle et al., 2012; Calabro et al., 2017; Fernandez \& Nieto, 2006; Graves \& Thomas, 2006). These theories can provide insights into 
the characteristics of family firms, which influence the likelihood of their internationalization and internationalization strategies, but they provide only limited insights into how the internationalization process evolves over time.

To understand the processes scholars have mainly drawn upon the Uppsala model and the alternative paths of born-globals and born-again globals (Calabro et al., 2016; Graves \& Thomas, 2008; Kontinen \& Ojala, 2012). These studies establish that the process predicted by the Uppsala model is the most common but pay less attention to the underlying mechanisms of experiential learning and networking in family firms. While Johanson and Vahlne (1977) recognize that firms can also reduce their international involvement, they do not directly integrate this option in the Uppsala model. For the Uppsala model to contribute to an understanding of internationalization as a discontinuous process, Santangelo and Meyer (2017) suggest that the evolutionary theory has to be incorporated to a larger degree in the model. Instead of adding a theory, we suggest that a closer integration of the key concepts of the behavioral theory of the firm can provide a better understanding of internationalization of family firms as a discontinuous process.

\section{The behavioral theory of the firm and family firms' internationalization}

The main question that Cyert and March (1963) address in the behavioral theory of the firm is how economic decisions like price and output decisions are made within the complex setting of a firm. They developed a set of sub-theories and key concepts to understand the micro-processes that underlie managerial decisions. 
Underlying assumptions. Cyert and March (1963) define an organization as a coalition of individuals. They assume that these individuals are likely to have different goals and these goals can conflict with each other. Second, individual goals result in organizational objectives through a continuous bargaining process among the individuals in a firm. The outcome of this bargaining process is not a maximizing solution but a satisfying solution because not all goals can be prioritized. Third, they assume that individuals are boundedly rational, meaning that individuals only know about a small fraction of all possible alternatives (Simon, 1972). To become aware of different alternative solutions to a problem, individuals search for information and only stop doing so when they find an alternative that provides a satisfactory solution to the problem. This search starts in the areas that a firm is most familiar with and the extent of the search is influenced by organizational slack. Finally, they assume that firms operate within an uncertain environment. An uncertain environment complicates the gathering of necessary information for taking strategic decisions. To deal with this, individuals use rules and standard operating procedures. The rules are influenced by the environment and the behavioral theory of the firm assumes that there is imperfect environmental matching so if the environment changes the decision-rules do not always change with the environment.

Sub-theories and key concepts. The behavioral theory of the firm includes a set of variable categories and a set of relational concepts. The variable categories are a set of three subtheories: organizational goals, organizational expectations, and organizational choice (Cyert \& March, 1963). The theory of organizational goals includes two sets of variables that affect organizational goals - the dimensions of goals and the aspiration level. The dimensions of goals focus on what is important within the coalition whereas the aspiration level is the performance target with regard to a certain goal. The theory of organizational expectations argues that organizational expectations are shaped by search activities. The success of search activities is influenced by the extent to which the goals are achieved and the amount of organizational slack. 
Where organizational slack is defined as the resources that are currently owned by a firm but are not necessary for its demand (Cyert \& March, 1992, p. 42). The theory of organizational choice holds that the variables that affect the choice are the variables that influence the definition of a problem, the standard decision rules, and the order in which alternatives are considered. Standard decision rules are in turn influenced by past experience and past organizational slack. In addition, Cyert and March (1963) developed four basic concepts which link the three theories and are key to an understanding of the decision-making process: quasi resolution of conflict, uncertainty avoidance, problemistic search, and organizational learning. These concepts are fundamental for understanding firms' decision-making processes (Cyert \& March, 1992). Most of the literature on family firms' internationalization provides an indirect link to the behavioral theory of the firm due to its focus on multiple goals and the emphasis on avoiding uncertainty in relation to SEW outcomes. A relatively small number of studies on family firms' internationalization can be directly linked to the behavioral theory of the firm through their focus on the role of organizational slack (Alessandri et al., 2018; Liu et al., 2011a) and learning (Cesinger et al., 2016a; Fernández-Olmos, Gargallo-Castel, \& Giner-Bagües, 2016). Table 1 provides an overview of the arguments in family firms' internationalization research in relation to the four basic concepts of the behavioral theory of the firm.

Table 1: Main findings in family business internationalization literature in relation to key concepts in the behavioral theory of the firm

\begin{tabular}{|c|c|c|c|}
\hline Key concept & Focus & Examples & Main findings \\
\hline $\begin{array}{l}\text { Quasi- } \\
\text { resolution of } \\
\text { goal conflict }\end{array}$ & $\begin{array}{l}\text { Different } \\
\text { goals }\end{array}$ & $\begin{array}{l}\text { Zahra (2003), } \\
\text { Westhead } \\
(2003), \\
\text { Gomez-Mejia, } \\
\text { Makri, } \\
\text { Kintana } \\
\text { (2010), Kano } \\
\text { and Verbeke }\end{array}$ & $\begin{array}{l}\text { The potential to create wealth for owner-managers } \\
\text { and future generations can result in a prioritization } \\
\text { of internationalization. However, a strong } \\
\text { emphasis on non-financial goals like a focus on } \\
\text { maintaining reputation and status in the local } \\
\text { community and protecting SEW can result in less } \\
\text { emphasis on internationalization. }\end{array}$ \\
\hline & & (2018) & $\begin{array}{l}\text { Moreover, a focus on enhancing the personal } \\
\text { quality of life and bias towards prioritizing }\end{array}$ \\
\hline
\end{tabular}


heritage assets can result in suboptimal internationalization decisions.

Influence of different coalitions

Uncertainty avoidance
Decisionrules
Problemistic search
Chen, Hsu and

Chang (2014),

Sanchez-

Bueno and

Usero (2014),

George,

Wiklund and

Zahra (2005),

Fernandez and

Nieto (2005),

Banalieva and

Eddleston

(2011), Holt

(2012),

Sciascia,

Massola,

Astrachan and

Pieper (2013),

d'Angelo,

Majocchi, and

Buck (2016)

Claver,

Rienda, and

Quer (2009),

Gomez-Mejia,

Makri,

Kintana

(2010),

Eddleston and

Banalieva

(2011), Lin

(2012),

Boellis,

Mariotti,

Minichilli and

Piscitello

(2016),

Initiation of internationali -zation

\section{Okoroafa}

(1999),

Kontinen and

Ojala (2011),

Fernandez-

Olmos,

Gargallo-

Castel and

Giner-Bagues

(2016)

Organization

al slack
A high degree of family ownership and control tends to reduce family firms' internationalization. External shareholders like venture capitalists may shift attention to internationalization, because they can provide access to external resources and they might align the owner-manager's interests with those of the top management team.

Besides external shareholders, external managers can have a positive influence on

internationalization because they bring a different set of skills and experience and can hence change the firm's priorities.
Potential downside effects on SEW are weighted heavier than potential financial gains, as a result of which family firms are less likely to internationalize.

When going international, family firms avoid uncertainty by entering markets that are relatively close and use operation modes that allow for flexibility and control.

Family firms prefer a narrow international scope or an irregular internationalization rhythm to maintain long-term family wealth.

Family firms do not regularly scan the international market place.

Internationalization tends to be initiated by unsolicited orders or through opportunities arising in the network.

\section{Liu, Lin and} Cheng (2011), Alessandri,
Presence of organizational slack does not necessarily facilitate internationalization of family firms, on the contrary a high degree of available 
Cerrato, slack might result in even stronger self-serving

Eddleston behavior and protection of SEW. However,

(2018) recoverable slack can stimulate a search for international opportunities.

Organization

al learning
Basly (2007),

Fernandez-

Olmos,

Gargallo-

Castel and

Giner-Bagues

(2016),

Cesinger,

Hughes,

Mensching,

Bouncke,

Fredrich and

Kraus (2016)
Family business conservatism may limit

organizational learning from international experiences.

However, family firms' long-term orientation can allow them to accumulate international experience and build the capabilities that are necessary for long-term growth.

Quasi resolution of conflict addresses the assumption that a firm is a coalition of individuals with different goals and therefore internal consensus is unlikely. The dimensions of goals address what is perceived as important. Cyert and March (1993) suggest taking into account the goals of different sub-units in the firm, compared to non-family firms, the boundaries of the family firm are extended and consider the coalition of individuals in the firm on the one hand and the owning-family on the other. This results in an overlap between the family unit and the non-family unit which, in turn, results in a larger variety of goals (Berrone, Cruz, \& GomezMejia, 2012; Gómez-Mejía et al., 2007; Kotlar \& De Massis, 2013). It is argued that internationalization is either facilitated because owner-managers perceive it as a strategy that facilitates the long-term growth of a firm and with that jobs for the next generation (Zahra, 2003) or family firms are unlikely to internationalize because they might not meet their nonfinancial goals if they do so (Cesinger et al., 2016b; Gomez-Mejia et al., 2010). Moreover, if family firms internationalize they might be more likely to take suboptimal internationalization decisions if family members involved in the firm pursue goals associated with enhancing the quality of their personal lives (Kano \& Verbeke, 2018). This bifurcation bias-that is, the 
prioritization of dysfunctional family assets over functional assets-has been observed in several studies on family firms' internationalization, even if these studies might not have made explicit use of this concept. For example, Bauweraerts et al. (2019) find that family CEOs might be more likely to prioritize family considerations and goals when taking exporting decision, unless they are supported — in strategic decision-making — by their board of directors.

According to the behavioral theory of the firm, goal conflict is resolved by prioritizing different goals at different points in time. Which goals are prioritized, depends on the power that different coalitions have in the bargaining process. A high degree of family ownership and control tends to put more emphasis on non-financial goals and with that reducing the likelihood of internationalization (Liu, Lin, \& Cheng, 2011b; Sanchez-Bueno \& Usero, 2014; Sciascia et al., 2012). Changes in the prioritization of goals are influenced by experience and the extent to which aspiration levels are met. This is a key aspect in the behavioral agency model and the relating SEW perspective. Internationalization can result in potential losses in SEW, that is, a failure to meet non-economic goals, which reduces the likelihood of family firms internationalizing (Gomez-Mejia et al., 2010). Literature on family firms' goals addresses goals as relatively static and hence, few scholars consider changes in the prioritization of goals or changes in aspirations over time. However, it is recognized that changes in succession, external involvement in a firm's management, and external ownership are associated with changes in family firms' internationalization strategies (Arregle et al., 2012; Kontinen \& Ojala, 2012; Sanchez-Bueno \& Usero, 2014) which could be an indication of changes in the prioritization of goals and the differences in aspirations.

Second, firms must deal with uncertainty in the decision-making process. Firms avoid uncertainty by using decision rules, focusing on short-term problems rather than the long-run, and by creating a negotiated environment through industry-wide good business practices, budgeting, and strategic planning (Cyert \& March,1963). The firms' aim is avoiding uncertainty 
while reaching a solution that satisfies the coalition and other demands of a firm rather than finding a maximizing solution. Potential gains or losses in SEW are weighted heavier than financial gains or losses by family firms (Gómez-Mejía et al., 2007). As such, a satisfying solution in family firms is likely to be one where losses in SEW are minimized which can be at the cost of financial gains (Martin \& Gomez-Mejia, 2016). Therefore, family firms can be more risk averse than non-family firms and are thus more likely to diversify within the home market than internationally (Gomez-Mejia et al., 2010). If family firms internationalize, they tend to enter markets that are relatively close (Eddleston \& Kellermanns, 2007; Gomez-Mejia et al., 2010) and use operation modes which allow them to be flexible and maintain control (Boellis et al., 2016).

Third, problemistic search addresses the idea that a search for solutions starts only in response to a problem (Cyert and March, 1963). A problem is recognized when a firm fails to satisfy one or more of its goals or when this is anticipated in the future. Whereas problemistic search is a key concept in the behavioral theory of the firm and in the Uppsala model (Johanson \& Vahlne, 1977) and addressed by Gómez-Mejía et al. (2007) in their discussion on SEW in family firms, few studies consider why family firms internationalize. Gallo and Sveen (1991) suggest that internationalization can be initiated by family firms for creating jobs for the next generation. Other studies (Jansson \& Söderman, 2012; Kontinen \& Ojala, 2011a) suggest that like many SMEs, family firms mainly respond to unsolicited orders and opportunities that arise in their formal networks. According to the behavioral theory of the firm, problemistic search continues until a satisfying alternative is found (Cyert \& March, 1963). The search for solutions is generally simple minded, that is, the search is conducted in an area that causes the problem and an area where previous solutions to similar problems have been found. Traditionally, literature on family firms' internationalization suggested that family firms have limited knowledge about international markets and limited access to international networks (Gallo \& 
Sveen, 1991; Kontinen \& Ojala, 2011b) which may impact their search strategies by focusing on solutions that are present in the domestic market. For example, Okoroafo (1999) found that family firms did not regularly scan international markets for opportunities. The search process was highly influenced by past experience which addresses the last key concept in the behavioral theory of the firm.

Within a firm, knowledge is translated into routines and decision-rules and these shape future decisions and learning (Levitt \& March, 1988). Based on learning from current experience, firms change their goals, shift attention to certain parts of the environment, and/or revise their procedures for the search (Cyert \& March, 1963). Literature on family firms' internationalization suggests that due to limited knowledge about internationalization and foreign markets, family firms experience barriers to internationalization (Gallo \& Sveen, 1991). However, there is also fear of losing control which can result in a conservative approach to internationalization and can limit the development of internationalization and market knowledge (Basly, 2007). External owners and non-family board members (Arregle et al., 2012; D’Angelo et al., 2016; Sciascia, Mazzola, Astrachan, \& Pieper, 2013) and strong network relations (Kontinen \& Ojala, 2011b) can help family firms overcome such barriers and stimulate their internationalization. However, these studies do not consider how family firms learn from their international experience and how this impacts internationalization decisions after the initial market entry.

\section{Future Research Directions on Family Firms’ De-internationalization} and Re-internationalization

The above comparison of the behavioral theory of the firm with literature on family firms' internationalization suggests that scholars have built on and borrowed different elements of the behavioral theory of the firm. However, whereas the behavioral theory of the firm provides a 
process perspective, literature on family firms' internationalization tends to incorporate mainly static elements of the behavioral theory of the firm. Next, we discuss areas for empirical research and future research questions that arise when taking the behavioral theory of the firm as a lens for studying internationalization of family firms as a discontinuous process. As a starting point, we use the four key concepts that Cyert and March (1963) introduced as being essential for understanding decision-making. Incorporating all four concepts provides a more comprehensive view, but also the opportunity to highlight avenues of research that so far have received less attention. Table 2 provides an overview of future research areas and relevant research questions that can be asked to deepen our current understanding of the internationalization process of family firms, with a specific focus on de-internationalization and re-internationalization. 
Table 2: Summary of the areas for empirical research

\begin{tabular}{|c|c|c|}
\hline & De-internationalization & Re-internationalization \\
\hline $\begin{array}{l}\text { Quasi resolution } \\
\text { of conflict }\end{array}$ & $\begin{array}{l}\text { Prioritization of goals } \\
\text { - Which goals are prioritized when family firms take a decision to } \\
\text { de-internationalize? } \\
\text { - How do non-financial goals influence family firms' de- } \\
\text { internationalization processes? } \\
\text { - Do family firms prioritize goals in the de-internationalization } \\
\text { process that are different from those of non-family firms? } \\
\text { Bargaining power } \\
\text { - Which coalitions in a family firm play a role in the de- } \\
\text { internationalization decision? } \\
\text { - How do external managers and owners influence the } \\
\text { prioritization of goals and subsequent de-internationalization? }\end{array}$ & $\begin{array}{l}\text { Prioritization of goals } \\
\text { - Which goals are prioritized when family firms take a decision } \\
\text { to re-internationalize? } \\
\text { - How do different goals influence the likelihood of re- } \\
\text { internationalization? } \\
\text { - Are the goals that are prioritized in times of re- } \\
\text { internationalization different from those prioritized during the } \\
\text { initial internationalization decision? } \\
\text { Bargaining power } \\
\text { - How do changes in ownership influence the likelihood of re- } \\
\text { internationalization? } \\
\text { To what extent and how do external managers influence re- } \\
\text { internationalization? }\end{array}$ \\
\hline $\begin{array}{l}\text { Uncertainty } \\
\text { avoidance }\end{array}$ & $\begin{array}{l}\text { Response to short-term problems } \\
\text { - How do family firms balance between long-term orientation and } \\
\text { de-internationalization as a potential response to short-term } \\
\text { problems? } \\
\text { Planning and routines } \\
\text { - How does the extent of planning for internationalization } \\
\text { influence the likelihood of de-internationalization? } \\
\text { - To what extent do family firms plan for de-internationalization? } \\
\text { - What kind of routines do family firms that go through multiple } \\
\text { de-internationalization experiences develop? }\end{array}$ & $\begin{array}{l}\text { Planning and routines } \\
\text { - To what extent do family firms plan for re-internationalization? } \\
\text { - How do international strategies and routines change when } \\
\text { family firms re-internationalize? } \\
\text { - What kind of routines do family firms develop when they go } \\
\text { through multiple re-internationalization experiences? } \\
\text { - To what extent are routines for re-internationalization in the } \\
\text { same market different from routines for a new market entry? }\end{array}$ \\
\hline
\end{tabular}


Table 2: Summary of the areas for empirical research (continued)

\begin{tabular}{|c|c|c|}
\hline & De-internationalization & Re-internationalization \\
\hline $\begin{array}{l}\text { Problemistic } \\
\text { search }\end{array}$ & $\begin{array}{l}\text { Failure to meet aspirations } \\
\text { - To what extent is de-internationalization triggered by a failure to } \\
\text { meet financial aspirations and to what extent is it triggered by a } \\
\text { failure to meet non-financial aspirations? } \\
\text { Search process } \\
\text { - Which alternatives do family firms consider when aspirations are } \\
\text { not met? Do family firms consider other alternatives before de- } \\
\text { internationalization as compared to non-family firms? } \\
\text { - How does family firms' patient capital influence the search } \\
\text { process before de-internationalization? } \\
\text { thow does family firms' patient capital influence the degree of } \\
\text { their de-internationalization? }\end{array}$ & $\begin{array}{l}\text { Failure to meet aspirations } \\
\text { - Which aspirations influence the search process that leads to re- } \\
\text { internationalization of family firms? Are these different from } \\
\text { those considered by non-family firms? } \\
\text { - Under what circumstances is re-internationalization a viable } \\
\text { strategy for family firms that do not meet their performance } \\
\text { aspirations? } \\
\text { Search process } \\
\text { - To what extent are the alternatives considered for re- } \\
\text { internationalization similar to the alternatives considered at the } \\
\text { initial foreign market entry? }\end{array}$ \\
\hline Learning & $\begin{array}{l}\text { - How does international experience influence a family firm's } \\
\text { decision to de-internationalize? Do family firms respond } \\
\text { differently to international experience as compared to non-family } \\
\text { firms? } \\
\text { - How does family ownership and control influence learning from } \\
\text { de-internationalization? } \\
\text { - How does the de-internationalization experience influence family } \\
\text { firms' aspirations? } \\
\text { - How does the de-internationalization experience influence the } \\
\text { family and its goals? }\end{array}$ & $\begin{array}{l}\text { - How do family firms utilize their past international experience } \\
\text { in the re-internationalization decision? } \\
\text { - How does the de-internationalization experience influence } \\
\text { family firms' likelihood of re-internationalization? } \\
\text { - How does a family firm's heterogeneity influence the extent to } \\
\text { which it uses past experience in the re-internationalization } \\
\text { decision? }\end{array}$ \\
\hline
\end{tabular}




\section{Goals and quasi resolution of goal conflict}

Besides heterogeneity in terms of family ownership, family firms can also be heterogeneous from the perspective of which goals they prioritize (Kammerlander \& Ganter, 2015) and, according to the behavioral theory of the firm, this can vary over time. Literature on family firms' internationalization mainly relies on the assumption that there are two types of goals financial and non-financial- which are relatively static over time. But the behavioral theory of the firm suggests that a larger variety of goals can be prioritized at different points of time (Cyert \& March, 1963). Following this idea, family business scholars (Berrone et al., 2012; Kotlar \& De Massis, 2013) have suggested a number of goals that family firms can pursue, which can be divided into financial family goals, non-financial family goals, financial nonfamily goals, and non-financial non-family goals. Financial family goals relate to family control and family wealth, while non-financial family goals relate to family harmony, social status, and identity. Further, financial non-family goals relate to growth, survival, and economic performance of the firm, and non-financial non-family goals are associated with internal serenity and external relations. While the distinction between different goals is made in the family business literature in general, family business internationalization literature mainly distinguishes between financial and non-financial goals and rarely studies the impact of different goals empirically. Although it is true that poor performance, so a difficulty in meeting financial non-family goals, is identified as a major reason for de-internationalization (McDermott, 2010; Dominguez \& Mayrhofer, 2017), due to the variety of goals present within the family firm the final decision might be driven by different goals. Which goals are prioritized, depends on the framing of the situation, meaning that an expected current loss in SEW can result in a decision that is different from the one taken for expected future gains in financial wealth (Gomez-Mejia et al., 2010; Gomez-Mejia, Patel, \& Zellweger, 2018; Martin \& Gomez-Mejia, 2016). Different non-financial goals can also result in diverse behavioral 
outcomes. For example, a focus on emotions can result in organizational inertia (Kammerlander and Ganter, 2015). This could be a potential reason for family firms to continue international activities, despite financial losses. On the other hand, a desire for control and power can result in timely recognition of changes in the environment thereby generating a response that is beneficial for meeting economic goals (Kammerlander and Ganter, 2015), which can take the form of timely de-internationalization or later re-internationalization. Like the notion that prioritization of non-financial goals can result in foregoing financial goals, non-financial goals can conflict with each other resulting in shifting priorities between different non-financial goals over time (Chua, Chrisman, \& De Massis, 2015).

Time might come into play as well. Balancing financial and non-financial goals might require a 'mixed gamble' logic ( e.g., Gomez-Mejia et al., 2014, 2017, 2018; Kotlar, Signori, De Massis, \& Vismara, 2018), entailing complex trade-offs among current (now) and perspective (future) financial and non-financial goals (Chirico et al., 2020). While a few studies have used the mix-gamble logic in study of family firms' internationalization (e.g. Alessandri et al., 2018), additional insights on (de)internationalization decisions over time can be gained by considering the priority that family firms may attribute to current financial goals versus prospective non-financial goals or vice-versa. This also relates the potential of bifurcation bias, which is an expression of bounded rationality reflected in the de facto prioritization of dysfunctional family assets over functional non-family assets (especially human assets) in the short and medium-term internationalization (Verbeke \& Kano, 2012, Kano \& Verbeke, 2018). Mixed gamble logic and bifurcation bias might influence the (dis)continuous internationalization of family firms where financial and non-financial (family) considerations are intertwined in an evolutionary way.

While the distinction between financial and non-financial goals is prominent in literature on family firms' internationalization, the distinction between family and non-family goals is 
less common. However, non-family goals potentially play an important role in changes in the international activities of the firm. Recruitment of new managers, for instance, influences de-internationalization as well as re-internationalization (Boddewyn, 1983; Dominguez \& Mayrhofer, 2017). Following the behavioral theory of the firm, this can result in changes in the coalition and power of different coalitions within the firm, potential for goal conflict and possibly a stronger focus on non-family goals within the decision making process of the family firm. Family business internationalization literature has so far, rarely addressed these underlying mechanisms, but doing so can provide new insights in the dynamics of the internationalization process of family firms. Following the discussion so far, some questions that can be addressed in future research are: Which goals are prioritized when family firms take a decision to de-internationalize or re-internationalize? How do external managers and owners influence the prioritization of goals and the subsequent deinternationalization? Which goals are pursued during the de-internationalization and reinternationalization processes?

Changes in the prioritization of goals can occur as a result of changing bargaining power. Whereas succession might be a driver of internationalization, questions arise as to how changes in family ownership and generational changes influence discontinuity in the internationalization process. Changes in the percentage of family ownership and succession can result in changes in the bargaining powers of different individuals in a family firm and the owning family (Arregle et al., 2012; Fernandez \& Nieto, 2006; Okoroafo, 1999b). It has been established that different degrees of family ownership, involvement in the management, and changes in family ownership through succession might also influence internationalization (Mitter, Duller, Feldbauer-Durstmüller, \& Kraus, 2014; Pukall \& Calabrò, 2014). This can result in changes in the bargaining powers of different coalitions and prioritization of different goals (Cyert \& March, 1963). Since changes in management might be a necessary prerequisite 
for de-internationalization (Boddewyn, 1983; Dominguez \& Mayrhofer, 2017), not only the recruitment of external managers can influence de-internationalization and reinternationalization, also changes in family ownership and involvement can potentially result in a change in the prioritization of goals and the internationalization strategy. Hence, to extend our understanding of family firms' internationalization as a discontinuous process, future research can consider how changes in the bargaining powers of a family firm's owners and managers change the prioritization of goals and how this is related to decisions on deinternationalization and re-internationalization. Recognizing the different coalitions in a firm and the possible changes in their bargaining powers over time raises research questions like: How do changes in ownership influence de-internationalization and re-internationalization?

\section{Uncertainty avoidance}

Family firms' internationalization can potentially benefit from a long-term orientation within the firm because family firms do not expect direct returns on investments and therefore have more time to learn from their experiences (Zahra, 2003). This is at odds with the behavioral theory of the firm which argues that firms avoid uncertainty by acknowledging that they cannot anticipate future events correctly and instead solve pressing problems rather than having a longterm focus (Cyert \& March, 1963). The SEW perspective is more in line with this notion in the behavioral theory of the firm because it argues that family firms tend to respond to short-term problems that put SEW at risk (Gomez-Mejia et al., 2010). To reconcile these two different notions, Kammerlander and Ganter (2015) suggest that different goals can be associated with different time horizons. Trade-offs and inter-relations between short-term responses to problems and the family firms' long-term orientation can vary across different types of strategic decisions and this is often highly complex (Lumpkin \& Brigham, 2011). The extent to which de-internationalization and re-internationalization might be influenced by long-term orientation 
versus short-term responses to problems can potentially explain the degree of deinternationalization and the approach to re-internationalization by family firms. For example, intermittent exporting is often associated with an ad hoc response to short-term external opportunities (Samiee \& Walters, 1991), while more committed exporters might first continue to commit for some more time trying to address the problems in the market before taking a decision to de-internationalize (Matthyssens \& Pauwels, 2000). Hence, questions can be raised about how family firms balance between a long-term orientation and responses to short-term problems in their internationalization processes in general and about the timing of the deinternationalization and re-internationalization in particular to extent the current understanding of family firm internationalization beyond the initial stages.

In addition to responding to short-term problems, firms avoid uncertainty by developing a negotiated environment through aspects like industry traditions and strategic plans and routines (Cyert \& March, 1963). While some internationalization strategies are identified that help family firms avoid uncertainty, the behavioral theory of the firm can provide a richer understanding of this by focusing on strategic planning and routines. Strategic planning is not only important for international growth, since most firms will go through some form of deinternationalization at some point in time, firms might also consider strategies for deinternationalization (Welch \& Luostarinen, 1988). Family firms' strategic planning and business routines are expected to differ from those of non-family firms because of the overlap between the family and the firm which influences strategic planning (Gersick, Lansberg, Desjardins, \& Dunn, 1999). Several reasons have been provided for why family firms are less likely to develop strategic plans including lack of knowledge about foreign markets, lack of necessary tools to scan the environment, challenges in incorporating the family's goals, and owner-manager's reluctance to plan because it reduces decision-making flexibility (Ward, 1988). In particular, de-internationalization can be related to poor planning of the initial 
international entry (Reiljan, 2006) pointing towards the relevance of understanding how and to what extent family firms plan their internationalization and the subsequent likelihood of deinternationalization. In addition, the extent to which family businesses adjust their plans for international growth when they decide to re-internationalize can be questioned. In family firms, strongly held family values and routines might provide a distinct frame of reference for decision-making and strategic planning which influences strategic planning, actions, and outcomes (Hall, Melin, \& Nordqvist, 2008); these are also likely to influence the extent to which adjustments are made when family firms re-internationalize. While recent findings indicate that firms in general do not adjust their operation modes when they re-internationalize (Surdu et al., 2018a), these characteristics might influence the likelihood of family firms' reinternationalizing and the extent to which plans and routines change in comparison to the initial internationalization. Although general insights exist on strategic planning in family firms and family firm routines, our current understanding on how these play a role in the internationalization process of family firms in order to deal with uncertainty is limited. Hence, future research can address questions about the extent to which family firms plan for deinternationalization and re-internationalization and to what extent family firms develop routines to deal with discontinuities in the internationalization process.

\section{Problemistic search}

According to Cyert and March (1963), financial performance that is below aspirations triggers a search process. As stated before, de-internationalization is often associated with poor financial performance (Dominguez \& Mayrhofer, 2017; Reiljan, 2006), suggesting that performance is below aspirations before firms de-internationalize. Since family firms tend to prioritize nonfinancial goals in their decision-making processes, it can be questioned whether the search process that results in de-internationalization in family firms is always triggered by a failure to 
meet financial goals. Similarly, initial market entry is associated with performance below aspiration levels which results in a search for new ways of doing business, resulting in more risk taking and increased commitment to internationalization (Cyert \& March, 1963; Wennberg \& Holmquist, 2008). Whereas it can be argued that the same holds true for reinternationalization, several scholars have suggested that re-internationalization is not the same as the initial internationalization because of the de-internationalization experience (Javalgi et al., 2011; Welch \& Welch, 2009).

Several factors can influence re-internationalization, of which a change in management is an important one because new managers are less influenced by negative emotions associated with de-internationalization (Dominguez \& Mayrhofer, 2017; Javalgi et al., 2011). However, family firms often have a lower turnover in their management teams as compared to non-family firms due to the involvement of the family (Stewart \& Hitt, 2012). Hence, for family firms the solutions that they search for are also likely to be relatively stable. For example, if internationalization has led to positive results in the past, they might pursue the same strategy again. However, it can also be argued that re-internationalization is less likely to be considered because of potential negative experiences associated with de-internationalization (Javalgi et al., 2011).

Hence, for family firms the type of solutions searched for is also likely to be relatively stable. This raises questions about the motivations for re-internationalization of family firms like which kind of problems or opportunities do family firms respond to when they reinternationalize, are these problems different from those of non-family firms, and do family firms respond to different problems when they re-internationalize than they do during their initial internationalization efforts?

A firm starts its search in areas that it is familiar with (Cyert \& March, 1963). Hence, when search is initiated, questions arise about the alternatives considered and how this is 
influenced by a family firm's characteristics. Because family firms are characterized by patient capital (Sirmon \& Hitt, 2003), de-internationalization might not be the first option considered when performance is below financial aspirations. When considering different types of goals that family firms can prioritize, there can be different responses to a failure to meet financial goals. For example, due to patient capital, family firms might want to be more willing to continue to invest even though the performance is below aspirations as compared to non-family firms and they search for different alternatives to increase profitability in the market.

However, following the SEW logic, current threats to family firms' SEW can have the opposite effect and increase chances of de-internationalization among these firms. Little is known about the process that leads to de-internationalization (Jackson et al., 2005) and even less about re-internationalization (Welch \& Welch, 2009). Questions about the problems that family firms respond to when they de-internationalize and re-internationalize, the processes that these problems trigger, and the variety of alternatives considered before de-internationalizing or re-internationalizing can provide new insights into the internationalization of family firms as a discontinuous process.

Finally, family firms' characteristics can result in different perceptions of what is a satisfying solution. Due to concerns about SEW and due to limited resources, family firms prefer certain international operation modes over others (Boellis et al., 2016; Gallo \& Sveen, 1991) and these factors might influence de-internationalization and re-internationalization as well. De-internationalization can take different forms like reduced commitment to a foreign market by changing to an operation mode that requires less resources, complete withdrawal from one foreign market but continued operations in others, or complete de-internationalization from all foreign markets (Turcan, 2011).

Moreover, family firms tend to be strongly embedded in the local environment of the home market with strong local relationships (Berrone et al., 2012; Kontinen \& Ojala, 2011b) 
and by supporting and subsidizing institutions (Campopiano, De Massis, \& Chirico, 2014). This local embeddedness can result in a preference for complete de-internationalization since family firms have more knowledge about the home market and the local environment. However, recently it is found that international family firms can pursue niche strategies which increase their international presence (Hennart et al., 2017). For these firms, complete deinternationalization might not be a satisfying solution because it threatens their SEW so they might consider other solutions instead. Hence, incorporating such family firms' characteristics is needed to fully understand the responses to the problems that arise. Similarly, reinternationalization can be concerned about entry into the same markets as the firm previously de-internationalized from or different foreign markets and the use of the same or different operation modes (Surdu et al., 2018a; Welch \& Welch, 2009).

Family firms are less likely to search for solutions that are new and increase chances of unexpected outcomes as compared to non-family firms (Gómez-Mejía et al., 2007). This might increase the likelihood of these firms entering the same or similar markets following the same operation modes. Hence, future research can provide new insights into family firms' internationalization as a discontinuous process by considering which family firms' characteristics and goals are associated with which type of satisfying solutions for deinternationalization and re-internationalization.

\section{Learning}

Existing research suggests that family firms are limited in their internationalization due to limitations in their knowledge about internationalization. However, existing literature on internationalization of family firms rarely considers experiential learning from internationalization. Family firms' characteristics can have different effects on their learning from international experience (Basly, 2007; Zahra, 2012). In line with a facilitative approach, 
family firms can be a setting where learning is stimulated more than in non-family firms because success and the long-term survival of a firm and a family's wealth depend on learning and using new skills for addressing challenges and opportunities (Zahra, 2012). Moreover, family cohesion, alignment of goals among individuals, and a higher frequency of meetings at which information is shared can facilitate learning within the owning-family and the firm (Basly, 2007). A restrictive approach suggests that family firms' core assumptions, beliefs, and routines can result in resistance or ignoring information that is not in line with these characteristics (Davis, 1983). Moreover, the presence of a dominant decision-maker can reduce the variety in knowledge flows into the company thus limiting learning experiences (Zahra, 2012).

An interpretation of new information is influenced by the family's routines and decisionrules and following literature on SEW, family firms might be reluctant to de-internationalize if they expect a potential loss to their SEW, even if this means that they have to accept some financial losses. Hence, the characteristics of family firms and decision-rules can result in different interpretations of the knowledge gained from international experience and hence different responses to challenges in a foreign market. Relevant questions can help address family firms' learning from international experience, the likelihood and form of deinternationalization, and how family firms' routines and decision-rules influence deinternationalization decisions.

Given their de-internationalization experience, the likelihood and strategies for reinternationalization might be different for family firms as compared to non-family firms. Usually individuals need time to reflect on experiences and incorporate this knowledge in their current strategies. When de-internationalization is associated with failure, more time might be needed to forget the negative experience (Javalgi et al., 2011; Welch \& Welch, 2009). For the owning family, besides being a source of income, the firm is also a source of pride as it reflects 
the family's identity. As a result, de-internationalization can trigger a stronger negative emotional response in the owning-family and family members involved in the firm than in managers of non-family firms (Shepherd, 2003). This negative emotional response can result in focusing on activities associated with the actual de-internationalization, rather than reflecting on what led to the de-internationalization. This means that subsequent learning from experiences might be limited.

Hence, if re-internationalization is considered a viable strategy at all, the question arises: to what extent do family firms adjust their internationalization strategies based on their learning from previous experiences? In line with the notion of learning in the behavioral theory of the firm, future research could examine how experiences associated with de-internationalization and re-internationalization influence future strategic decisions and whether differences exist between family and non-family firms. As there are different perspectives on how family ownership can influence learning, it will be valuable to recognize that family firms are a heterogeneous group of firms with different knowledge bases and opportunities for knowledge sharing. Hence, different family firms can have different ways of incorporating internationalization and de-internationalization experiences in their decisions.

Learning not only influences behavior but it can also influence the prioritization of goals. The behavioral theory of the firm suggests that learning from experience can influence goals in two ways. First, aspiration levels can be adjusted depending on past personal achievements as well as the achievements of a reference group (Cyert \& March, 1963). Although goals are central in understanding family firms' behavior, learning from experience and the subsequent effect of this learning on a firm and family's goals are not often acknowledged in literature on family firms (Williams Jr, Pieper, Kellermanns, \& Astrachan, 2018). One possible reason for this could be that in recent years the SEW perspective has strongly influenced research on family firms. However, this perspective is based on the prospect theory which mainly focuses 
on adjusting behavior in response to a risk of not meeting aspirations (Wiseman \& GomezMejia, 1998) rather than how these responses affect aspirations.

Besides potential adjustments in behavior as a result of a search process, the behavioral theory of the firm also suggests that aspiration levels associated with different goals can be adjusted. Changes in aspiration levels can change the degree of commitment to a foreign market. In existing literature on family firms' internationalization, family firms' goals are implicitly assumed as static. However, a more dynamic view can be provided by building on key concepts of the behavioral theory of the firm's goal adjustments. This leads to research questions on how family firms adjust their aspiration levels in response to learning from the initial internationalization and de-internationalization experience and whether family firms respond differently to a de-internationalization experience as compared to non-family firms.

Second, experience can shift attention to different goals (Cyert \& March, 1963). Family firms and family members cannot respond to a large variety of goals at once. Most of the literature on family firms' internationalization examines how family owners influence international development and only a few studies have examined internationalization's influence on family firms' financial performance (Fernández-Olmos et al., 2016). Little attention is also paid to how experiences associated with internationalization influence a family and its goals.

The impact of internationalization experiences is likely to relate to the characteristics and the stage of internationalization. For example, de-internationalization from one export market which only captured a small percentage of a firm's sales might have a different impact on the family, its learning, and its ability to achieve goals than divestment of a foreign subsidiary. In case there is the divestment of a foreign subsidiary, commitment to foreign operations and therefore the time and money invested are higher. These have a more serious impact on the firm's financial wealth (Benito \& Welch, 1997). Since financial wealth is a pre-requisite for a 
family firm to survive and achieve non-financial goals (Holt, Pearson, Carr, \& Barnett, 2017), divestment of foreign subsidiaries can have a stronger influence on family cohesion and the family's ability to achieve non-financial goals than exiting from an export market. Moreover, the family's attachment to the firm's international operations that are stopped can trigger shifts in attention.

De-internationalization might be more difficult for family members who worked to create international activities (Feldman, Amit, \& Villalonga, 2013). In these situations, conflicts might arise when family members prioritize different goals which can destabilize the family (Williams et al., 2018). This suggests that besides considering the potential impact of international experience on a family and the attention it pays to its goals, questions can be raised about contingency conditions like the degree of initial international commitment or emotional involvement in the international activities that the family firm de-internationalizes which influence a shift in attention between different goals.

\section{Conclusions}

The conceptual study in this chapter contributes to our scholarly understanding of family firms' internationalization in two ways. First, we outline how the behavioral theory of the firm, as one of the main theories underlying studies on family firms as well as internationalization process studies, has so far contributed to our knowledge of family firms' internationalization processes. This includes an overview of which elements of the behavioral theory of the firm that have been less influential in previous research. We conclude that literature on family firms' internationalization has borrowed some of the concepts of the behavioral theory of the firm, but disregarded others. The notion that firms are composed by a coalition of individuals with a variety of goals is incorporated by distinguishing between financial and non-financial goals in family firms' internationalization. However, in general, research on family firms has 
established a larger variety of goals and as such distinguishing between financial and nonfinancial goals might be too narrow a focus for understanding internationalization as a discontinuous process.

Moreover, family firms avoid uncertainty in their internationalization processes by entering similar markets and by preferring certain operation modes over others. The behavioral theory of the firm provides a process perspective which is less prominent in literature on family firms' internationalization because it treats goals as relatively static. The notions of learning and problemistic search, which are prominent in internationalization process studies, have also received little attention.

Second, we contribute by building on the four key concepts that Cyert and March (1963) introduced as essential for an understanding of decision-making processes to provide ideas for new research. The future research agenda is focused on areas that scholars might address to more fully understand the internationalization of family firms as a discontinuous process. We rely on the notion that family firms are a coalition of individuals with different goals leading to that family firms may prioritize different goals at different points in time. In doing so, our study opens up for seeing a family's and firm's goals and their impact on internationalization as a discontinuous process.

In addition, incorporating the notion of problemistic search can provide new insights into which problems family firms respond to when they de-internationalize or re-internationalize. It can also help to understand whether a variety of alternative strategies are considered before deinternationalization to prevent it or whether de-internationalization is the only option for ensuring that aspirations are met. Similarly, incorporating the idea of problemistic search can provide insights into why family firms re-internationalize. Finally, we suggest that to what extent family firms learn from their past international experience and incorporate this learning in future strategic planning and organizational routines can influence the internationalization 
process. As such, learning is essential for understanding how and why firms de-internationalize or re-internationalize and how different phases in the internationalization process are linked to each other.

\section{References}

Alessandri, T. M., Cerrato, D., \& Eddleston, K. A. (2018). The mixed gamble of internationalization in family and nonfamily firms: The moderating role of organizational slack. Global Strategy Journal, 8(1), 46-72. doi:10.1002/gsj.1201

Arregle, J. L., Duran, P., Hitt, M. A., \& Van Essen, M. (2017). Why is family firms' internationalization unique? A meta-analysis. Entrepreneurship Theory and Practice, 41(5), $801-831$

Arregle, J. L., Naldi, L., Nordqvist, M., \& Hitt, M. A. (2012). Internationalization of FamilyControlled Firms: A Study of the Effects of External Involvement in Governance. Entrepreneurship Theory and Practice, 36(6), 1115-1143. doi:10.1111/j.1540$6520.2012 .00541 . x$

Banalieva, E. R., \& Eddleston, K. A. (2011). Home-region focus and performance of family firms: The role of family vs non-family leaders. Journal of International Business Studies, 42(8), 1060-1072.

Bauweraerts, J., Sciascia, S., Naldi, L., \& Mazzola, P. (2019). Family CEO and board service: Turning the tide for export scope in family SMEs. International Business Review 28(5) 101583.

Basly, S. (2007). The internationalization of family SME: An organizational learning and knowledge development perspective. Baltic Journal of Management, 2(2), 154-180.

Benito, G. R. (1997). Divestment of foreign production operations. Applied Economics, 29(10), 13651378.

Benito, G. R., \& Welch, L. S. (1997). De-internationalization. MIR: Management International Review, 7-25. 
Bernini, M., Du, J., \& Love, J. H. (2016). Explaining intermittent exporting: Exit and conditional reentry in export markets. Journal of International Business Studies, 1-19. doi:10.1057/s41267016-0015-2

Berrone, P., Cruz, C., \& Gomez-Mejia, L. R. (2012). Socioemotional wealth in family firms theoretical dimensions, assessment approaches, and agenda for future research. Family Business Review, 25(3), 258-279.

Boddewyn, J. J. (1979). Foreign divestment: magnitude and factors. Journal of International Business Studies, 21-27.

Boddewyn, J. J. (1983). Foreign and domestic divestment and investment decisions: like or unlike? Journal of International Business Studies, 14(3), 23-35.

Boellis, A., Mariotti, S., Minichilli, A., \& Piscitello, L. (2016). Family involvement and firms' establishment mode choice in foreign markets. Journal of International Business Studies, 47(8), 929-950.

Buckley, P. J., \& Casson, M. C. (1998). Analyzing foreign market entry strategies: Extending the internalization approach. Journal of International Business Studies, 29(3), 539-561.

Cairns, P., Quinn, B., Alexander, N., \& Doherty, A. M. (2010). The role of leadership in international retail divestment. European Business Review, 22(1), 25-42.

Calabro, A., Brogi, M., \& Torchia, M. (2016). What Does Really Matter in the Internationalization of Small and Medium-Sized Family Businesses? Journal of small business management, 54(2), 679-696. doi:10.1111/jsbm.12165

Calabro, A., Campopiano, G., Basco, R., \& Pukall, T. (2017). Governance structure and internationalization of family-controlled firms: The mediating role of international entrepreneurial orientation. European Management Journal, 35(2), 238-248. doi:10.1016/j.emj.2016.04.007

Calabrò, A., Mussolino, D., \& Huse, M. (2009). The role of board of directors in the internationalisation process of small and medium sized family businesses. International Journal of Globalisation and Small Business, 3(4), 393-411. doi:10.1504/IJGSB.2009.032259 
Campopiano, G., De Massis, A., \& Chirico, F. (2014). Firm philanthropy in small-and medium-sized family firms: The effects of family involvement in ownership and management. Family Business Review, 27(3), 244-258.

Casillas, J. C., \& Moreno-Menéndez, A. M. (2017). International business \& family business: Potential dialogue between disciplines. European Journal of Family Business, 7(1-2), 25-40.

Cesinger, B., Hughes, M., Mensching, H., Bouncken, R., Fredrich, V., \& Kraus, S. (2016a). A socioemotional wealth perspective on how collaboration intensity, trust, and international market knowledge affect family firms' multinationality. Journal of World Business, 51(4), 586-599. doi:10.1016/j.jwb.2016.02.004

Cesinger, B., Hughes, M., Mensching, H., Bouncken, R., Fredrich, V., \& Kraus, S. (2016b). A socioemotional wealth perspective on how collaboration intensity, trust, and international market knowledge affect family firms' multinationality. Journal of World Business, 51(4), 586-599. doi:https://doi.org/10.1016/j.jwb.2016.02.004

Chen, H. L., Hsu, W. T., \& Chang, C. Y. (2014). Family ownership, institutional ownership, and internationalization of SMEs. Journal of small business management, 52(4), 771-789.

Chirico, F., Criaco, G., Baù, M., Naldi, L., Gomez-Mejia, L. R., \& Kotlar, J. (2020). To patent or not to patent: That is the question. Intellectual property protection in family firms. Entrepreneurship Theory and Practice, 44(2), 339-367.

Choquette, E. (2018). Import-based market experience and firms' exit from export markets. Journal of International Business Studies, 1-27.

Chua, J. H., Chrisman, J. J., \& De Massis, A. (2015). A closer look at socioemotional wealth: its flows, stocks, and prospects for moving forward. Entrepreneurship Theory and Practice, 39(2), 173-182.

Claver, E., Rienda, L., \& Quer, D. (2007). The internationalisation process in family firms: Choice of market entry strategies. Journal of General Management, 33(1), 1-14.

Claver, E., Rienda, L., \& Quer, D. (2009). Family firms' international commitment: The influence of family-related factors. Family Business Review, 22(2), 125-135. 
Coviello, N., Kano, L. \& Liesch, P. (2017) Adapting the Uppsala model to a modern world: Macrocontext and microfoundations. Journal of International Business Studies 48(9), 1151-1164.

Crick, D. (2004). UK SMEs' decision to discontinue exporting: an exploratory investigation into practices within the clothing industry. Journal of Business Venturing, 19(4), 561-587.

Cyert, R. M., \& March, J. G. (1963). A behavioral theory of the firm. Englewood Cliffs, NJ, 2.

Cyert, R. M., \& March, J. G. (1992). A behavioral theory of the firm (2nd ed.). Oxford, United Kingdom: Blackwell Publishers.

D’Angelo, A., Majocchi, A., \& Buck, T. (2016). External managers, family ownership and the scope of SME internationalization. Journal of World Business.

Davis, P. (1983). Realizing the potential of the family business. Organizational dynamics, 12(1), 4756.

Delios, A., \& Beamish, P. W. (2001). Survival and profitability: The roles of experience and intangible assets in foreign subsidiary performance. Academy of management Journal, 44(5), 1028-1038.

Dominguez, N., \& Mayrhofer, U. (2017). Internationalization stages of traditional SMEs: Increasing, decreasing and re-increasing commitment to foreign markets. International Business Review, 26(6), 1051-1063.

Eddleston, K. A., \& Kellermanns, F. W. (2007). Destructive and productive family relationships: A stewardship theory perspective. Journal of Business Venturing, 22(4), 545-565.

Ellis, P. D. (2011). Social ties and international entrepreneurship: Opportunities and constraints affecting firm internationalization. Journal of International Business Studies, 42(1), 99-127.

Feldman, E. R., Amit, R. R., \& Villalonga, B. (2013). Corporate Divestitures and Family Control. Paper presented at the Academy of Management Proceedings.

Fernández-Olmos, M., Gargallo-Castel, A., \& Giner-Bagües, E. (2016). Internationalisation and performance in Spanish family SMES: The W-curve. BRQ Business Research Quarterly, 19(2), 122-136.

Fernandez, Z., \& Nieto, M. J. (2006). Impact of ownership on the international involvement of SMEs. Journal of International Business Studies, 37(3), 340-351. doi:10.1057/palgrave.jibs.8400196 
Fernández, Z., \& Nieto, M. J. (2005). Internationalization Strategy of Small and Medium-Sized Family Businesses: Some Influential Factors. Family Business Review, 18(1), 77-89.

Fitzgerald, D., \& Haller, S. (2018). Exporters and shocks. Journal of International Economics, 113, 154-171. doi:10.1016/j.jinteco.2018.04.005

Gallo, M. A., \& Sveen, J. (1991). Internationalizing the Family Business: Facilitating and Restraining Factors. Family Business Review, 4(2), 181-190. doi:10.1111/j.1741-6248.1991.00181.x

Gavetti, G., Greve, H. R., Levinthal, D. A., \& Ocasio, W. (2012). The behavioral theory of the firm: Assessment and prospects. The academy of management annals, 6(1), 1-40.

George, G., Wiklund, J., \& Zahra, S. A. (2005). Ownership and the internationalization of small firms. Journal of Management, 31(2), 210-233. doi:10.1177/0149206304271760

Gersick, K. E., Lansberg, I., Desjardins, M., \& Dunn, B. (1999). Stages and transitions: Managing change in the family business. Family Business Review, 12(4), 287-297.

Gómez-Mejía, L. R., Haynes, K. T., Núñez-Nickel, M., Jacobson, K. J., \& Moyano-Fuentes, J. (2007). Socioemotional wealth and business risks in family-controlled firms: Evidence from Spanish olive oil mills. Administrative Science Quarterly, 52(1), 106-137.

Gomez-Mejia, L. R., Makri, M., \& Kintana, M. L. (2010). Diversification Decisions in FamilyControlled Firms. Journal of Management Studies, 47(2), 223-252. doi:10.1111/j.14676486.2009.00889.x

Gomez-Mejia, L. R., Patel, P. C., \& Zellweger, T. M. (2018). In the horns of the dilemma: Socioemotional wealth, financial wealth, and acquisitions in family firms. Journal of Management, 44(4), 1369-1397.

Graves, C., \& Shan, Y. G. (2014). An empirical analysis of the effect of internationalization on the performance of unlisted family and nonfamily firms in Australia. Family Business Review, 27(2), 142-160.

Graves, C., \& Thomas, J. (2006). Internationalization of Australian family businesses: A managerial capabilities perspective. Family Business Review, 19(3), 207-224. 
Graves, C., \& Thomas, J. (2008). Determinants of the internationalization pathways of family firms: An examination of family influence. Family Business Review, 21(2), 151-167. doi:10.1111/j.1741-6248.2008.00119.x

Hall, A., Melin, L., \& Nordqvist, M. (2008). 14 Understanding strategizing in the family business context. Handbook of research on family business, 253.

Hennart, J.-F., Majocchi, A., \& Forlani, E. (2017). The myth of the stay-at-home family firm: How family-managed SMEs can overcome their internationalization limitations. Journal of International Business Studies, 1-25.

Holt, D. T., Pearson, A. W., Carr, J. C., \& Barnett, T. (2017). Family firm (s) outcomes model: Structuring financial and nonfinancial outcomes across the family and firm. Family Business Review, 30(2), 182-202.

Håkanson, L., \& Kappen, P. (2017) The 'casino model'of internationalization: An alternative Uppsala paradigm. Journal of International Business Studies 48(9), 1103-1113.

Jackson, P., Mellahi, K., \& Sparks, L. (2005). Shutting up shop: understanding the international exit process in retailing. The Service Industries Journal, 25(3), 355-371.

Jansson, H., \& Söderman, S. (2012). Initial internationalization of Chinese privately owned enterprises - the take-off process. Thunderbird International Business Review, 54(2), 183-194.

Javalgi, R. R. G., Deligonul, S., Dixit, A., \& Cavusgil, S. T. (2011). International market reentry: A review and research framework. International Business Review, 20(4), 377-393.

Johanson, J., \& Vahlne, J.-E. (1977). The internationalization process of the firm-a model of knowledge development and increasing foreign market commitments. Journal of International Business Studies, 23-32.

Kammerlander, N., \& Ganter, M. (2015). An attention-based view of family firm adaptation to discontinuous technological change: Exploring the role of family CEOs' noneconomic goals. Journal of Product Innovation Management, 32(3), 361-383.

Kano, L., \& Verbeke, A. (2018). Family firm internationalization: Heritage assets and the impact of bifurcation bias. Global Strategy Journal, 8(1), 158-183. doi:10.1002/gsj.1186 
Kontinen, T., \& Ojala, A. (2010). The internationalization of family businesses: A review of extant research. Journal of Family Business Strategy, 1(2), 97-107.

Kontinen, T., \& Ojala, A. (2011a). International opportunity recognition among small and mediumsized family firms. Journal of Small Business Management, 49(3), 490-514.

Kontinen, T., \& Ojala, A. (2011b). Social capital in relation to the foreign market entry and post-entry operations of family SMEs. Journal of international entrepreneurship, 9(2), 133-151.

Kontinen, T., \& Ojala, A. (2012). Internationalization pathways among family-owned SMEs. International Marketing Review, 29(5), 496-518. doi:10.1108/02651331211260359

Kotlar, J., \& De Massis, A. (2013). Goal setting in family firms: Goal diversity, social interactions, and collective commitment to family-centered goals. Entrepreneurship Theory and Practice, $37(6), 1263-1288$

Kraus, S., Mensching, H., Calabrò, A., Cheng, C.-F., \& Filser, M. (2016). Family firm internationalization: a configurational approach. Journal of Business research, 69(11), 54735478.

Levitt, B., \& March, J. G. (1988). Organizational learning. Annual review of sociology, 14(1), 319338.

Liu, Y., Lin, W.-T., \& Cheng, K.-Y. (2011a). Family ownership and the international involvement of Taiwan's high-technology firms: The moderating effect of high-discretion organizational slack. Management and Organization Review, 7(2), 201-222.

Liu, Y. S., Lin, W. T., \& Cheng, K. Y. (2011b). Family Ownership and the International Involvement of Taiwan's High-Technology Firms: The Moderating Effect of High-Discretion Organizational Slack. Management and Organization Review, 7(2), 201-222. doi:10.1111/j.1740-8784.2011.00220.x

Lumpkin, G. T., \& Brigham, K. H. (2011). Long-term orientation and intertemporal choice in family firms. Entrepreneurship Theory and Practice, 35(6), 1149-1169.

Martin, G., \& Gomez-Mejia, L. (2016). The relationship between socioemotional and financial wealth: Re-visiting family firm decision making. Management Research: Journal of the Iberoamerican Academy of Management, 14(3), 215-233. 
McDermott, M. C. (2010). Foreign divestment: The neglected area of international business?. International Studies of Management \& Organization, 40(4), 37-53.

Matthyssens, P., \& Pauwels, P. (2000). Uncovering international market-exit processes: A comparative case study. Psychology \& Marketing, 17(8), 697-719.

Metsola, Jaakko, et al. "Process in family business internationalisation: The state of the art and ways forward." International Business Review (2020): 101665.

Mitter, C., Duller, C., Feldbauer-Durstmüller, B., \& Kraus, S. (2014). Internationalization of family firms: The effect of ownership and governance. Review of Managerial Science, 8(1), 1-28. doi:10.1007/s11846-012-0093-x

Mohr, A., Batsakis, G., \& Stone, Z. (2018). Explaining the effect of rapid internationalization on horizontal foreign divestment in the retail sector: An extended Penrosean perspective. Journal of International Business Studies, 49(7), 779-808. doi:10.1057/s41267-017-0138-0

Okoroafo, S. C. (1999a). Internationalization of family businesses: Evidence from Northwest Ohio, U.S.A. Family Business Review, 12(2), 147-158. doi:10.1111/j.1741-6248.1999.00147.x

Okoroafo, S. C. (1999b). Internationalization of family businesses: Evidence from Northwest Ohio, USA. Family Business Review, 12(2), 147-158.

Okoroafo, S. C., \& Koh, A. C. (2009). Family Businesses' Views on Internationalization: Do they Differ by Generations? International Business Research, 3(1), P22.

Oviatt, B. M., \& McDougall, P. P. (1994). Toward a theory of international new ventures. Journal of International Business Studies, 45-64.

Pukall, T. J., \& Calabrò, A. (2014). The internationalization of family firms: A critical review and integrative model. Family Business Review, 27(2), 103-125.

Reiljan, E. (2006). DE-INTERNATIONALIZATION MOTIVES: A THEORETICAL FRAMEWORK. Tartu University, 144-154.

Reuber, A. R. (2016). An Assemblage-Theoretic Perspective on the Internationalization Processes of Family Firms. Entrepreneurship Theory and Practice, 40(6), 1269-1286.

Samiee, S., \& Walters, P. G. (1991). Segmenting corporate exporting activities: sporadic versus regular exporters. Journal of the Academy of Marketing Science, 19(2), 93-104. 
Sanchez-Bueno, M. J., \& Usero, B. (2014). How may the nature of family firms explain the decisions concerning international diversification? Journal of Business research, 67(7), 1311-1320. doi:http://dx.doi.org/10.1016/j.jbusres.2013.09.003

Santangelo, G. D., \& Meyer, K. E. (2017). Internationalization as an evolutionary process. Journal of International Business Studies, 48(9), 1114-1130. doi:10.1057/s41267-017-0119-3

Sciascia, S., Mazzola, P., Astrachan, J. H., \& Pieper, T. M. (2012). The role of family ownership in international entrepreneurship: Exploring nonlinear effects. Small Business Economics, 38(1), $15-31$.

Sciascia, S., Mazzola, P., Astrachan, J. H., \& Pieper, T. M. (2013). Family Involvement in the Board of Directors: Effects on Sales Internationalization. Journal of small business management, 51(1), 83-99. doi:10.1111/j.1540-627X.2012.00373.x

Shepherd, D. A. (2003). Learning from business failure: Propositions of grief recovery for the selfemployed. Academy of Management Review, 28(2), 318-328.

Simon, H. A. (1972). Theories of bounded rationality. Decision and organization, 1(1), 161-176.

Sirmon, D. G., \& Hitt, M. A. (2003). Managing resources: Linking unique resources, management, and wealth creation in family firms. Entrepreneurship Theory and Practice, 27(4), 339-358.

Sousa, C. M., \& Tan, Q. (2015). Exit from a foreign market: do poor performance, strategic fit, cultural distance, and international experience matter? Journal of International Marketing, 23(4), 84-104.

Stewart, A., \& Hitt, M. A. (2012). Why can'ta family business be more like a nonfamily business? Modes of professionalization in family firms. Family Business Review, 25(1), 58-86.

Surdu, I., Mellahi, K., \& Glaister, K. W. (2018a). Once bitten, not necessarily shy? Determinants of foreign market re-entry commitment strategies. Journal of International Business Studies, 130.

Surdu, I., Mellahi, K., Glaister, K. W., \& Nardella, G. (2018b). Why wait? Organizational learning, institutional quality and the speed of foreign market re-entry after initial entry and exit. Journal of World Business, 53(6), 911-929. doi:10.1016/j.jwb.2018.07.008 
Tagiuri, R., \& Davis, J. A. (1992). On the goals of successful family companies. Family Business Review, 5(1), 43-62.

Turcan, R. V. (2011). De-internationalization: A conceptualization. Paper presented at the AIB-UK \& Ireland Chapter Conference'International Business: New Challenges, New Forms, New Practices,'April.

Ward, J. L. (1988). The special role of strategic planning for family businesses. Family Business Review, 1(2), 105-117.

Welch, C., Nummela, N. \& Liesch, P. "The internationalization process model revisited: An agenda for future research." (2016): 783-804.

Welch, C., \& Paavilainen-Mäntymäki, E. (2014). Putting process (back) In: Research on the internationalization process of the firm. International Journal of Management Reviews, 16(1), $2-23$.

Welch, C. L., \& Welch, L. S. (2009). Re-internationalisation: Exploration and conceptualisation. International Business Review, 18(6), 567-577.

Welch, L. S., \& Luostarinen, R. (1988). Internationalization: evolution of a concept. The Internationalization of the firm, 83-98.

Wennberg, K., \& Holmquist, C. (2008). Problemistic search and international entrepreneurship. European Management Journal, 26(6), 441-454.

Williams Jr, R. I., Pieper, T. M., Kellermanns, F. W., \& Astrachan, J. H. (2018). Family firm goals and their effects on strategy, family and organization behavior: A review and research agenda. International Journal of Management Reviews, 20, S63-S82.

Wiseman, R. M., \& Gomez-Mejia, L. R. (1998). A behavioral agency model of managerial risk taking. Academy of Management Review, 23(1), 133-153.

Vissak, T. (2010). Nonlinear internationalization: a neglected topic in international business research. Advances in International Management, 23, 559-580.

Vissak, T., \& Francioni, B. (2013). Serial nonlinear internationalization in practice: A case study. International Business Review, 22(6), 951-962. doi:10.1016/j.ibusrev.2013.01.010 
Vissak, T., Francioni, B., \& Musso, F. (2012). MVM's Nonlinear Internationalization: A Case Study. Journal of East-West Business, 18(4), 275-300. doi:10.1080/10669868.2012.736081

Zahra, S. A. (2003). International expansion of U.S. manufacturing family businesses: The effect of ownership and involvement. Journal of Business Venturing, 18(4), 495-512. doi:10.1016/S0883-9026(03)00057-0

Zahra, S. A. (2012). Organizational learning and entrepreneurship in family firms: exploring the moderating effect of ownership and cohesion. Small Business Economics, 38(1), 51-65. doi:10.1007/s11187-010-9266-7 
